http://dx.doi.org/10.11646/zootaxa.3755.2.2

http://zoobank.org/urn:lsid:zoobank.org:pub:2BA7877A-8CDF-4658-A789-F18EE565422B

\title{
Identification and character analysis of the Acerentomidae (Protura) of the northeastern Palearctic (Protura: Acerentomidae)
}

\section{JULIA SHRUBOVYCH}

Institute of Systematics and Evolution of Animals, Polish Academy of Sciences, ul. Stawkowska 17, 31-016 Kraków, Poland and State Museum of Natural History, Ukrainian National Academy of Sciences, Teatral'na St. 18, UA 79008 L'viv, Ukraine.

E-mail:shrubovych@gmail.com

\begin{abstract}
This paper is a summary of proturan fauna from Siberia and the Russian Far East, collectively termed the northeastern Palearctic. Special attention is given to the analysis of Acerentomidae, which is extraordinarily diverse in these regions (31 species). A key to species and a brief exposition of distribution of each genus are provided. A redescription of $I m-$ adateiella sharovi is presented, additional morphological characters are added for Nipponentomon khabarovskense, N. bidentatum, Yamatentomon yamato and Callientomon chinensis, and additional collection data are given for $Y$. yamato, C. chinensis, Nipponentomon jaceki and N. nippon. A cladistic analysis is presented of hypothetical relationships among the discussed acerentomid taxa. A scheme for ventral porotaxy is proposed, and the taxonomic importance of porotaxic characters within Acerentomata is discussed. Some biogeographical and phylogenetic considerations are given.
\end{abstract}

Key words: taxonomy, cladistic analysis, porotaxy, key, redescription, new records

\section{Introduction}

Protura inhabit soils worldwide, excepting the Arctic and Antarctic regions (Pass \& Szucsich 2011). In general the taxonomy and distribution of this group is poorly known. Several taxonomic monographs have been published, including Protura of the world (Tuxen 1964), Europe (Nosek 1973), Japan (Imadaté 1974) and China (Yin 1999). The known world fauna of Protura currently comprises 808 species in 75 genera. The proturan fauna of China (approximately 200 species) and Japan (88 species according to Kaneko et al. 2012), neighbors to the northeastern Palearctic, have been studied most completely. The proturan fauna of Europe comprises approximately 180 species of Protura.

The larger territories of the northeastern Palearctic (Siberia and the Russian Far East) had been scarcely investigated. Szeptycki (1988) described three new genera and 10 new species from the Altaj mountains. This paper remains the only work on Siberian Protura. For the Russian Far East Martynova (1977) described the new species Acerella sharovi from Snow Valley near Magadan and Nakamura (2004) recorded nine species from Khabarovsk, four of which were new.

The objectives of this paper are to present a reliable means of identification for the 35 currently recognized species of the studied territory, analyze the phylogenetic importance of morphological characters within Acerentomata, and discuss the biogeographic considerations of the proturan fauna of the northeastern Palearctic.

\section{Material and methods}

Specimens were collected by several individuals at different localities in Siberia and the Russian Far East during the last 30 years and deposited in the collections of various institutions. Binomens and their authors and dates are given in Table 1. 


\section{Acknowledgements}

I am very obliged to Sofia Stebaeva, Anatoly Babenko, Mikhail Potapov, Nikolaj Rjabinin, Louis Deharveng and Anne Bedos for providing the rich Protura material. I would like to express my gratitude to Wanda M. Weiner, Osami Nakamura, Cyrille D'Haese, Jacek Szwedo, Andrew Novikoff and Derek Okonkowski for their help in preparing the manuscript. I was able to study the type materials through the help of Dr. V.A. Krivokhatsky (head curator of Zoological Institute RAS), Dr. V. Kuznetsova (St. Petersburg) and Dr. A. Nadachovska (Krakow). This work was supported by grant NN303 068334 from the Ministry of Science and Higher Education, Poland.

\section{References}

Bernard, E.S. \& Biechele, L.T. (2008) Nipponentomon pembertonense, n. sp. (Protura: Acerentomidae) from Maryland. Proceedings of the Biological Society of Washington, 121, 438-444. http://dx.doi.org/10.2988/08-23.1

Bu, Y., Shrubovych, J. \& Yin, W. (2011) Two new species of genus Hesperentomon Price, 1960 (Protura, Hesperentomidae) from Northern China. Zootaxa, 2885, 55-64.

Bu, Y., Su, Y. \& Yin, W. (2011) First record of Protura from Helan Mountain, Northwest China (Hexapoda, Protura). Acta zootaxonomica Sinica, 36 (3), 803-807.

Bu, Y. \& Wu, D.H. (2012) Revision of Chinese Yamatentomon, with description of one new species and redescription of Yamatentomon yamato (Protura: Acerentomata: Acerentomidae). Florida Entomologist, 95 (4), 839-847. http://dx.doi.org/10.1653/024.095.0404

Bu, Y., Wu, D., Shrubovych, J. \& Yin, W. (2013) New Nipponentomon species from northern Asia (Protura: Acerentomata, Nipponentomidae). Zootaxa, 3636, 525-546. http://dx.doi.org/10.11646/zootaxa.3636.4.2

Bu, Y. \& Xie, R. (2007) The new species of Proturan from Northeast, China (Protura, Acerentomidae). Acta Zootaxonomica Sinica, 32 (1), 56-60.

Bu, Y. \& Yin, W. (2007) The Protura from Xinjiang, Northwestern China. Zootaxa, 1437, $29-46$.

Bu, Y. \& Yin, W. (2008) Occurrence of Nosekiella Rusek 1974 and Nienna Szeptycki 1988 (Protura: Nipponentomidae: Verrucoentominae) in China. Annales de la Societe Entomologique de France, 44, 201-207. http://dx.doi.org/10.1080/00379271.2008.10697556

Bu, Y. \& Yin, W. (2011) New genus Liaoxientulus (Protura, Acerentomidae) from Northeast China. Acta Zootaxonomica Sinica, 36 (4), 854-860.

Condé, B. (1961) Protoures Protentomonidés de la région malgache. Bulletin du Muséum National D'Histoire naturelle, Paris, $33(4), 415-420$.

Darlington, P.J. (1957) Zoogeography, the geographical distribution of animals. Wiley, New York, 675 pp.

Francois, J. (2003) Analyse cladistique de l'orde des Protoures (Hexapoda, Protura). Bulletin de la Sociéte Entomologique de France, 108, 109-125.

Francois, J. (2006) Analyse cladistique du genre Acerentomon Silvestri, 1907 (Protura, Acerentomidae). Bulletin de la Société Entomologique de France, 111, 5-10.

Galli, L. \& Capurro, M. (2013) Acerentulus shrubovychae sp. nov. from Italy (Protura: Acerentomidae). Zootaxa, 3609, 431436. http://dx.doi.org/10.11646/zootaxa.3609.4.5

Goloboff, P. (2008) Nona. Version 2.0. Retrieved May 25, 2008. Available from: www.cladistics.com (accessed 24 December 2013)

Imadaté, G. (1964) Taxonomic arrangement of Japanese Protura (II). Bulletin of the National Science Museum, 7, $263-293$.

Imadaté, G. (1974) Protura (Insecta), Fauna Japonica. Keigaku Publishing, Tokyo, 320 pp.

Imadaté, G. (1981) Occurence of Nosekiella (Protura, Acerentomidae) in Japan. Annotationes Zoologicae Japonenses, 54, 142 146.

Imadaté, G. \& Yosii, R. (1956) Two new species of Protura from Japan. Insecta Samurana, 20, 11-16.

Kaneko, N., Minamiya, Y., Nakamura, O., Saito, M. \& Hashimoto, M. (2012) Species assemblage and biogeography of Japanese Protura (Hexapoda) in forest soils. Diversity, 4 (3), 318-333. http://dx.doi.org/10.3390/d4030318

Martynova, E.F. (1977) Acerella sharovi sp. n. (Protura, Acerentomidae) from Magadan district. Zoologicheskii Zhurnal, 56, 164-167. [in Russian]

Mayr, E. (1969) Principles of systematic zoology. McGraw-Hill, New York, 428 pp.

Mayr, E. (1971) Methods and strategies in taxonomic research. Systematic Zoology, 20 (4), 426-433. http://dx.doi.org/10.2307/2412118

McDowall, R.M. (1973) Zoogeography and taxonomy. Tuatara, 20 (2), 88-95. 
Nakamura, O. (2004) Protura from Khabarovsk, the Russian Far East. Edaphologia, 75, 17-35.

Nixon, K.C. (1999) Winclada (Beta), Version 0.9.9. Published by the author, Ithaca, New York.

Nosek, J (1973) The European Protura. Muséum d'Historie Naturelle, Genève, 345 pp.

Nosek, J (1978) Key and diagnoses of Proturan genera of the world. Annotationes Zoologicae et Botanicae, Bratislava, 122, 159.

Pass, G. \& Szucsich, N.U. (2011) 100 years of research on the Protura: many secrets still retained. Soil Organisms, 83 (3), 309 334.

Rusek, J. (1974) Zur Taxonomie einiger Gattungen der Familie Acerentomidae (Insecta, Protura). Acta Entomologica Bohemoslovaca, 71, 260-281.

Rusek, J., Shrubovych, J. \& Szeptycki, A. (2012) Head porotaxy and chaetotaxy of order Acerentomata (Protura). Zootaxa, 3262, 54-61.

Shrubovych, J. (2009a) Nipponentomon jaceki sp. nov. from the Russian Far East (Protura: Acerentomidae, Nipponentominae). Zootaxa, 2231, 55-61.

Shrubovych, J. (2009b) Acerentomon szeptyckii sp. n. (Protura: Acerentomidae) from Ukraine. Acta Zoologica Cracoviensia, 52B (1-2), 9-15. http://dx.doi.org/10.3409/azc.52b_1-2.09-15

Shrubovych, J. (2010a) Two new species of the genus Baculentulus from the Russian Far East (Protura: Acerentomidae, Berberentulinae). Zootaxa, 2619, 39-48.

Shrubovych, J. (2010b) Redescription of Hesperentomon tianshanicum Martynova, 1970 and key to Hesperentomon species. Zootaxa, 2720, 28-34.

Shrubovych, J. (2011) Redescription of Verrucoentomon montanum new status (=Acerella montana Martynova) (Protura: Acerentomidae, Nipponentominae). Zootaxa, 2743, 63-67.

Shrubovych, J. \& Bernard, E.C. (2012) Two new species of Verrucoentomon (Protura: Acerentomidae, Nipponentominae) and a key to species. Annals of the Entomological Society of America, 105 (5), 628-637. http://dx.doi.org/10.1603/an11175

Shrubovych, J. \& Bernard, E.C. (2013) Review of Tuxenentulus and Fjellbergella species (Protura: Acerentomidae, Acerentominae). Annals of the Entomological Society of America, 106 (6), 673-683. http://dx.doi.org/10.1603/an12116

Shrubovych, J. \& Rusek, J. (2010) Sugaentulus andrzeji sp. nov. from Siberia, Russia. Zootaxa, 2720, 59-68.

Shrubovych, J., Rusek, J. \& Bernard, E.C. (2012) Redefinition and four new species of Yavanna Szeptycki and comparison with Nosekiella Rusek (Protura: Acerentomidae: Nipponentominae). Annals of the Entomological Society of America, 105 (1), 3-19. http://dx.doi.org/10.1603/an11119

Shrubovych, J., Rusek, J. \& Bernard, E.C. (2014) Revision of Vesiculentomon, Nosekientomon n. g. (Protura: Acerentomidae, Nipponentominae), and a key to genera of Nipponentominae. Annals of the Entomological Society of America, 107 (1), 74 80 . http://dx.doi.org/10.1603/an12135

Shrubovych, J. \& Smykla, J. (2012) Review of the genus Paracerella Imadaté (Protura: Acerentomidae, Nipponentominae) with identification key and description of a new species. Zootaxa, 3509, 69-76.

Shrubovych, J. \& Szeptycki, A. (2006) Noldo kaprusii n. sp., a new species from Crimea (Protura: Nipponentomidae). Genus, 17 (2), 151-158.

Szeptycki, A. (1980) Polish Protura I. Genus Acerentomon Silvestri, 1907. Polskie Pismo Entomologiczne, 50, $311-392$.

Szeptycki, A. (1988) New genera and species of Protura from the Altai Mts. Acta Zoologica Cracoviensia, 31, $297-362$.

Szeptycki, A. (1993) Gracilentulus species of "gracilis" group (Protura, Berberentomidae). Polskie Pismo Entomologiczne, 35, 381-411.

Szeptycki, A. (1995) The porotaxy of Protura - a preliminary report. Polskie Pismo Entomologiczne, 64 (1-4), 63-67.

Szeptycki, A. (1997) The present knowledge of Protura. Fragmenta Faunistica, 40 (28), 307-311.

Szeptycki, A. (2007) Catalogue of the world Protura. Acta Zoologica Cracoviensia, 50, 1-210.

Tang, B.W. (1990) A cladistic study on five genera of Protentomidae (Apterygota: Protura). Contributions from Shanghai Institute of Entomology, 9, 116-120.

Tuxen, S.L. (1963) Phylogenetical trends in the Protura. As shown by relationship between recent genera. Zeitschrift für Zoologische Systematik und Evolutionsforschung, 1, 277-310.

Tuxen, S.L. (1964) The Protura. Hermann, Paris, 360 pp.

Tuxen, S.L. (1967) Australian Protura, their phylogeny and zoogeography. Zeitschrift für Zoologische Systematik und Evolutionsforschung, 5, 1-53.

Tuxen, S.L. (1977a) Ecology and zoogeography of the Brasilian Protura (Insecta). Studies of Neotropical Fauna and Environment, 12, 225-247.

Tuxen, S.L. (1977b) The genus Berberentulus (Insecta, Protura) with a key and phylogenetical considerations. Revue d'Ecologie et de Biologie du Sol, 14, 597-611.

Tuxen, S.L. (1978) Protura (Insecta) and Brasil During 400 million years of continental drift. Studies on Neotropical Fauna and Environment, 13, 23-50. 
http://dx.doi.org/10.1080/01650527809360530

Tuxen, S.L. (1980) Notes on the Silvestridia complex (Insecta, Protura) in Madagascar. Revue d'Écologie et du Biologie de Sol, 17, 437-443.

Tuxen, S.L. (1981) The systematic importance of "the striate band" and the abdominal legs in Acerentomidae (Insecta, Protura). With a tentative key to acerentomid genera. Entomologica Scandinavica, 15, 125-140.

Udvardy, M.D.F. (1969) Dynamic zoogeography. With special reference to land animals. Van Nostrand Reinhold, New York, $445 \mathrm{pp}$.

Yin, W.Y. (1980) Studies on Chinese Protura: Description of new species and new genera of the family Acerentomidae with discussions on their phylogenetic significance. Contributions from Shanghai Institute of Entomology, 1, 135-156. [in Chinese with English summary]

Yin, W.Y. (1984a) A new idea of phylogeny of Protura with approach to its origin and systematic position. Sciencia Sinica, 27, 149-160.

Yin, W.Y. (1984b) The discovery of Proturentomon and description of two new species of Hesperentomon from China (Protura: Protentomidae, Hesperentomidae). Acta Entomologica Sinica, 27, 418-425. [in Chinese with English summary]

Yin, W.Y. (1999) Fauna Sinica. Arthropoda. Protura. Science Press, Beijing, 510 pp. [in Chinese with English summary] 